Volume VII - Article 9

\title{
Legal Defect Protected by Article 42 of the CISG : A Wolf in Sheep's Clothing
}

\author{
Thomas M. Beline ${ }^{1}$ \\ Spring 2007 \\ Copyright (C) University of Pittsburgh School of Law \\ Journal of Technology Law and Policy
}

\begin{abstract}
The United Nations Convention on Contracts for the International Sale of Goods (CISG) was written to facilitate and increase certainty in international sales transactions. Unfortunately, a major shortcoming of the CISG is in regard to sales of goods that are subject to intellectual or industrial property rights. This article discusses the problems with a uniform substantive law to govern sales of goods that are subject to intellectual property rights and counsels practitioners to include contract clauses to govern any disputes that may arise in relation to a claim brought by a third party asserting ownership to the intellectual or industrial property rights of the goods.
\end{abstract}

\footnotetext{
${ }^{1}$ University of Pittsburgh, School of Law, J.D., expected 2007. Editor-in-Chief, Journal of Technology Law \& Policy. The author would like to thank Andrew M. Lukashunas and Emily K. Ruger for their remarkable editing skills and their ability to ignore our close friendship to provide me with scathing criticism, Professor Ronald A. Brand for inspiring me to pursue a career in international business transactions, and Professor Harry M. Flechtner for his invaluable guidance and encouragement to refine my writing abilities and write on a challenging topic that has little-to-no existing scholarly commentary.
} 


\section{Table of Contents}

I. Introduction 3

II. Article 42: The Genesis, Inclusion, and Failings in Construction ..........4 A. Should intellectual and industrial property rights have a place in uniform international contract law?

B. Article 42 requirement of delivery free from any right or claim

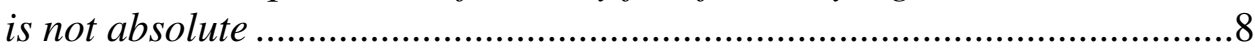

C. Article 43 implementation requirements and procedure.......................17

III. Counterfeit goods as non-conforming to the contract under Article 35

IV. The Practitioners' Corner: A short guide to dealing with industrial and intellectual rights vested in a third party in the transnational sale of goods 25

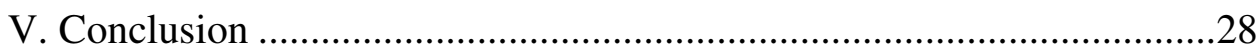




\section{Introduction}

Due to increasing volumes of transnational sales of goods, a uniform substantive law was needed to govern disputes. While in many respects the application of a uniform body of contract law has decreased transaction costs and resulted in greater predictability in dispute resolution, there is an inherent tension when a transnational body of law governs issues that had traditionally been territorially-based. This tension is particularly evident when considering intellectual and industrial property (hereinafter IIP) rights. ${ }^{2}$ This note will discuss the IIP issues that buyers and sellers should consider when entering into contracts for the sale of goods governed by the United Nations Convention on Contracts for the International Sale of Goods (hereinafter CISG). ${ }^{3}$ The ultimate recommendation from this author will be for the parties to contract out of the CISG with respect to the law applicable to any dispute concerning a claim made by a third party based in IIP.

The focus of this note will be illuminating problems that can arise for a buyer and seller relying on the substantive law of the CISG when the goods sold are encumbered by a legal defect. The note is divided into four sections. The first part of the analysis in section II will address the development and applicability of Article 42 discussing its genesis in uniform contract law and the problems in its drafting. In addition, this section will analyze the procedure under Article 43 implementing the protections of Article 42 with additional analysis from comparable requirements of Article 39, which deals with non-conforming goods. Section III will continue to

\footnotetext{
${ }^{2}$ This note will reflect the language chosen by the drafters for Article 42 of the United Nations Convention on Contracts for the International Sale of Goods. Secretariat, Commentary on the Draft Convention on Contracts for the International Sale of Goods, art. 40 n.1, U.N. Doc. A/Conf. 97/5 (Mar. 14, 1979) (noting "the term 'intellectual property' is usually understood to include 'industrial property," "but that it "was thought to be preferable to use the term 'industrial and intellectual property'.... in order to leave no question as to whether third-party claims based on, inter alia, an alleged infringement of a patent were covered by article 40 of this Convention.") [hereinafter Secretariat Commentary].

${ }^{3}$ See U.N. Conference on Contracts for the International Sale of Goods, Final Act (Apr. 10, 1980), U.N. Doc. A/Conf. 97/18, reprinted in 19 I.L.M. 668 (1980) [hereinafter CISG].
} 
analyze the convergence of a legal defect in the goods with non-conformity, discuss whether counterfeit goods can be non-conforming to the contract under Article 35 of the CISG, and discuss whether pursuing a remedy through this article instead of, or in addition to, Article 42 would be advantageous to the buyer. Section IV concludes with a discussion of sample contract clauses and the importance of including certain provisions within each clause.

\section{Article 42: The Genesis, Inclusion, and Failings in Construction}

Article 42

(1) The seller must deliver goods which are free from any right or claim of a third party based on industrial property or other intellectual property, of which at the time of the conclusion of the contract the seller knew or could not have been unaware, provided that the right or claim is based on industrial property or other intellectual property:

(a) under the law of the State where the goods will be resold or otherwise used, if it was contemplated by the parties at the time of the conclusion of the contract that the goods would be resold or otherwise used in that State; or

(b) in any other case, under the law of the State where the buyer has his place of business.

(2) The obligation of the seller under the preceding paragraph does not extend to cases where:

(a) at the time of the conclusion of the contract the buyer knew or could not have been unaware of the right or claim; or

(b) the right or claim results from the seller's compliance with technical drawings, designs, formulae or other such specifications furnished by the buyer. ${ }^{4}$

\section{A. Should intellectual and industrial property rights have a place in uniform international contract law?}

Although the requirement that a seller deliver goods free from third party claims based in IIP is common in domestic contract law, that same requirement is nascent in international commercial contract law. The United States, Germany and Spain have specific domestic laws concerning warranty and non-conformity of goods, within which are provisions dealing with

\footnotetext{
${ }^{4} I d$. art. 42 .
} 
rights or claims to goods made by a third party based in IIP. In the United States, the Uniform Commercial Code (hereinafter UCC) § 2-312(3) requires that "a seller who is a merchant regularly dealing in goods of the kind warrants that the goods shall be delivered free of the rightful claim of any third person by way of infringement or the like..."5 Similarly, German law $\S 435$ BGB requires that the goods be free from legal defects. ${ }^{6}$ The Spanish Civil Code Article 1474 requires that the seller shall indemnify the buyer for the lawful and peaceful possession of the good owned. ${ }^{7}$ Therefore, it is clear that domestic sales law protects a buyer against the receipt of goods encumbered by a right or claim asserted in relation to those goods by a third party.

The legal defect provisions of the UCC, German Code and Spanish Civil Code highlight the protections that are available for a buyer when domestic law is applied to the transaction. The similar language and similar protection of the codes suggests that most States applied a near uniform law in protecting against legal defect. Though there is a certain degree of uniformity in protection for the buyer among most domestic law, when that protection is placed into a body of uniform international substantive law, the result is significantly different. ${ }^{8}$ If the CISG had not included Article 42, then under the gap filling provision of Article 7(2) ${ }^{9}$, a domestic court could apply its own law to resolve a dispute relating to a third party claim based on IIP rights. Due to the fact that domestic law is rather uniform in protecting the buyer, the result of applying domestic law would actually lead to greater predictability and certainty than Article 42 currently offers.

\footnotetext{
${ }^{5}$ U.C.C. $\$ 2-312(3)$ (2001), available at http://www.law.cornell.edu/ucc/2/article2.htm\#s2-312.

${ }^{6}$ SiR BASIL MARKESINIS, HANNES UNBERATH \& ANGUS JOHNSTON, THE GERMAN LAW OF CONTRACT: A COMPARATIVE TREATISE 501 (2d ed. 2006).

${ }^{7}$ C.C. art. 1474, reprinted in SPANISH CiVIL CodE (Julio Romanach, Jr. trans., Lawrence Publishing Co. 1994).

${ }^{8}$ See infra Section II.

${ }^{9}$ CISG, supra note 3, art. 7(2). "Questions concerning matters governed by this Convention which are not expressly settled in it are to be settled in conformity with the general principles on which it is based or, in the absence of such principles, in conformity with the law applicable by virtue of the rules of private international law."
} 
It is instructive to look at the evolution of international sales law, specifically focusing on the Uniform Law for International Sales (hereinafter ULIS) ${ }^{10}$ as the precursor to the CISG. Under the ULIS, Article 52 protected the buyer against rights and claims by a third party asserted in relation to the goods sold. ${ }^{11}$ Although it is unclear whether IIP rights were meant to be included in Article 52, Professor John Honnold notes that Professor Tunc's commentary to Article 52 was limited specifically to "ownership" and physical title claims. ${ }^{12}$ Notably absent in Professor Tunc's commentary was legal title defect, which concerns claims to title based in IIP. The difference between "ownership defects" and "legal title defects" can be illustrated by the example of the sale of a stolen car (ownership defect) as opposed to the sale of a good produced by a patented process. In addition, CISG Article 41 is the current version of ULIS Article 52 and includes "only rights and claims which relate to property in the goods themselves by way of ownership, security interests in the goods, or the like."13 Thus, it seems that claims and rights based in IIP were not contemplated by the drafters of Article 52. Certainly it can be said that the drafters of the CISG did not recognize that IIP rights or claims had been included in Article 52.

Despite the failure of Article 52 to cover IIP rights or claims, the ULIS might not be completely silent on protection for third party IIP rights or claims. It is possible for IIP claims to fall within Article 33, which is the non-conformity provision of ULIS. Article 33(1)(d) requires that goods possess qualities necessary for ordinary and commercial use. Professor Honnold notes that under the ULIS, conformity of the goods sold was to be determined by the law of the

\footnotetext{
${ }^{10}$ Convention Relating to a Uniform Law on the International Sale of Goods, Final Act of the Diplomatic Conference on Unification of Law governing the International Sale of Goods, The Hague, Apr. 2-25, 1964, with the Uniform Law on the International Sale of Goods (ULIS) as an Annex, 1964, reprinted in 3 I.L.M. 854 (1964).

${ }^{11}$ ULIS, supra note 10 , art. 52.

${ }^{12}$ JOHN O. HONNOLD, UNIFORM LAW FOR INTERNATIONAL SALES UNDER THE 1980 UNITED NATIONS CONVENTION 292-97 (3d ed. 1999), available at http://www.cisg.law.pace.edu/cisg/biblio/ho42.html [hereinafter Honnold Treatise].

${ }^{13}$ Secretariat Commentary, supra note 2, art. 41, available at http://www.cisg.law.pace.edu/cisg/text/secomm/secomm-41.html.
} 
place at the time when risk passes. Therefore, if a patent exists only in State $\mathrm{B}^{14}$ and is in the public domain of State $S$, a seller would be responsible for infringement on the rights of a third party patent-owner under an Ex Ship ${ }^{15}$ contract but not Delivery Duty Paid (DDP). ${ }^{16}$ Therefore the selected Incoterm would change the requirements on each party beyond the traditional risk of loss. Additionally, problems could occur when the parties select an Incoterm that differs from the manner in which the contract is actually performed. ${ }^{17}$ In conjunction with the problem of whether the IIP rights were even considered in relation to Article 52, the disconnect that Article 33 analysis causes seemingly requires considerations of whether IIP rights should be included in any uniform international contract law.

Where domestic law limits the seller's obligations geographically, a uniform international contract law could exponentially increase a seller's responsibilities. This fundamental problem is perhaps why no steps had previously been taken to include IIP rights or claims. The 1976 Working Group deferred discussion of the inclusion of such an article. ${ }^{18}$ Further, the UNIDROIT Principles do not discuss IIP. ${ }^{19}$ The concern of expanding a seller's responsibility infinitely is highlighted in the Secretariat's Commentary to the 1978 Draft of then-Article 40 dealing with IIP claims. The Secretariat noted that the general rule of warranty against any infringement claim by a third party "is appropriate" in domestic transactions. ${ }^{20}$ The concern expressed by the Secretariat's commentary was that "the seller cannot be expected to have as

\footnotetext{
${ }^{14}$ For the purpose of this paper, State B will refer to the buyer's state, State S to the seller's state, and State X to any other state where the goods might be used by the buyer.

15 JAN RAMBERG, ICC GUIDE TO INCOTERMS 2000 (International Chamber of Commerce 2000).

${ }^{16}$ Honnold Treatise, supra note $12, \S 268 \mathrm{~B}$.

${ }^{17}$ See, e.g., if a buyer and seller include the term "c.i.f." in the contract, but the buyer pays for freight and through the usage of trade or course of dealing, the risk passes at another time than when the goods pass over the ship's rail, a court might find that actual performance of the contract outweighs any term in the contract.

${ }^{18}$ Honnold Treatise, supra note 12, § 269.

${ }^{19}$ UNIDROIT, Rome 1994, reprinted in 34 I.L.M. 1067 (1995).

${ }^{20}$ Secretariat Commentary, supra note 2, art. 42, (discussing how a seller should be responsible for any infringement that would occur in the country in which he is both producing and selling) available at http://www.cisg.law.pace.edu/cisg/text/secomm/secomm-42.html.
} 
complete knowledge of the status of [IIP]....rights which his goods might infringe as he would have in his own country." ${ }^{21}$ An additional concern was that the buyer could use the goods in a resale capacity in other countries at some point in the future, and an article granting protection would indefinitely extend the possibility of the seller being required to indemnify the buyer. Due to the disconnect of the ULIS as discussed above, combined with the tension of creating a transnational body of law to govern traditionally territorial-based rights, it is clear that the drafters of Article 42 faced a unique challenge.

\section{B. Article 42 requirement of delivery free from any right or claim is not absolute}

Article 42 at its most basic level requires that the seller deliver goods "which are free from any right or claim of a third party based on industrial property or other intellectual property...."22 The phrase "industrial property or other intellectual property" was adopted at the Diplomatic Conference at the suggestion of the World Intellectual Property Organization (hereinafter WIPO). ${ }^{23}$ WIPO considers that intellectual property includes all rights "resulting from intellectual activity in the industrial, scientific, literary or artistic fields." 24 Therefore, it seems that the industrial and intellectual property rights that would likely be infringed in the sale of goods would be limited to copyright, trademark and patents.

The language "right or claim" in Article 42 guarantees that the buyer will enjoy quiet title in possession of the goods. This specific language is also used in Article $41 .^{25}$ In the Secretariat's Commentary to that Article, it is noted that the seller has not only breached his

\footnotetext{
${ }^{21} I d$. (alteration in original).

${ }^{22}$ CISG, supra note 3, art. 42.

${ }^{23}$ Allen M. Shinn, Jr., Liabilities Under Article 42 of the U.N. Convention on the International Sale of Goods, 2 MinN. J. Global TRADE 115, 122 n.31 (1993) (citing Honnold Treatise, supra note 12) (noting that the term was first suggested by Finland and then withdrawn but later reintroduced by Argentina and adopted without discussion).

${ }^{24}$ Convention Establishing the World Intellectual Property Organization, art. 2, July 14, 1967, 828 U.N.T.S. 3.

${ }^{25}$ CISG, supra note 3 , art. 41.
} 
obligation if the claim by the third party is valid, but also whenever a claim can be made at all. ${ }^{26}$ "The reason for this rule is that once a third party has made a claim in respect of the goods, until the claim is resolved the buyer will face the possibility of litigation with and potential liability to the third party." 27 Professor Honnold goes on to state that the buyer should be protected in his normal expectation that he is "not purchasing a lawsuit."28

Although the UCC requires that a claim is "rightful," that requirement has been interpreted to include any claim that survives a Federal Rule of Civil Procedure Rule 11 challenge. ${ }^{29}$ While there is no discussion by any commentators to Article 42 about whether a buyer can seek indemnification from a seller for a frivolous claim asserted by a third party based in IIP, it seems settled in domestic procedural law that the buyer would be entitled to indemnification for costs associated with that claim by the party who brought it. ${ }^{30}$ This application of domestic law is consistent with the gap filling function of Article 7 discussed previously. Therefore, private international law points to the applicable procedural rules, and, as the rules are generally universal, the application of domestic procedural rules will result in the promotion of uniformity in the application of the CISG. ${ }^{31}$ Although it is true that the buyer will only be able to recover costs associated with the claim brought and not with his inability to use the goods he purchased until the claim is resolved, it seems entirely consistent with the underlying purpose of providing the buyer some relief but not extending potential liability of the seller infinitely.

\footnotetext{
${ }^{26}$ Secretariat Commentary, supra note 2, available at http://www.cisg.law.pace.edu/cisg/text/secomm/secomm41.html.

${ }^{27} \mathrm{Id}$.

${ }^{28}$ Honnold Treatise, supra note 12, available at http://www.cisg.law.pace.edu/cisg/biblio/ho41.html.

${ }^{29}$ U.C.C. $\S 2-312$ n.2 (2001) (commenting that the cause of action accrues when the breach occurs).

${ }^{30}$ See generally FED. R. CIV. P. 11; W. Kent Davis, The International View of Attorney Fees in Civil Suits: Why is the United States the "Odd Man Out" in How it Pays its Lawyers? 16 ARIZ. J. InT'L \& COMP. L. 361 (1999) (comparing and contrasting the loser pays rule in civil law).

${ }^{31}$ CISG, supra note 3 , art. 7.
} 
The basic requirement of delivering goods free from third party rights and claims based in IIP is restricted by explicit limitations. As opposed to Article 41 which requires the seller to "deliver goods which are free from any right or claim of a third party," 32 Article 42 employs the limitation that "at the time of the conclusion of the contract the seller knew or could not have been unaware" of the third party rights or claims based in IIP. ${ }^{33}$ The extent of the required "knowledge" is debated. Professor Honnold suggests that language such as "ought to have known" implies a duty to inquire, and because "could not have been unaware" was used by the drafters, the standard is closer to actual knowledge. ${ }^{34}$ Professor Peter Schlechtriem, on the other hand, suggests that the seller "must inform himself about the possible industrial or other intellectual property rights of third persons.",35

The famous "mussels case," decided by the Bundesgerichtshof is instructive as to the standard of inquiry required of the seller. ${ }^{36}$ In that case, the buyer purchased New Zealand mussels from a Swiss seller. ${ }^{37}$ However, the mussels were found to contain a level of cadmium that violated German food regulations. ${ }^{38}$ The buyer wanted to declare a fundamental breach due to non-conformity of the goods. ${ }^{39}$ However, the court held that the laws of the seller's place of business controlled whether the goods were conforming. ${ }^{40}$ Professor Schlechtriem criticizes this decision noting that what is decisive is the particular purpose of the goods; "if the seller knows where the goods are intended to be used, then he will usually be expected to have taken the

\footnotetext{
${ }^{32}$ CISG, supra note 3, art. 41 (emphasis added).

${ }^{33}$ CISG, supra note 3, art. 42.

${ }^{34}$ Honnold Treatise, supra note $12, \S 270 \mathrm{C}$.

35 Peter SCHLEChTRIEM, UNIFORM SALES LAW -THE UN-CONVENTION ON CONTRACTS FOR THE INTERNATIONAL SALE OF GOODS 73 (1986), available at http://www.cisg.law.pace.edu/cisg/biblio/schlechtriem-42.html.

${ }^{36}$ CLOUT Case No. 123 [Bundesgerichtshof [BGH] [Federal Court of Justice] Mar. 8, 1995, VIII ZR 159/94 (F.R.G),], available at http://cisgw3.law.pace.edu/cases/950308g3.html.

${ }^{37} I d$.

${ }^{38} \mathrm{Id}$.

${ }^{39} \mathrm{Id}$.

${ }^{40}$ Id.
} 
factors that influence the possibility of their use in that country into consideration."41 Although the case does not require a seller to inquire, Professor Schlechtriem notes that many courts and arbitral tribunals require this of the seller. In light of the seller's knowledge of the use of the goods, when considered in combination with the geographical limitations on the seller's knowledge, it seems to follow that the seller should be required to inquire into the existence of third party IIP rights. ${ }^{42}$ In addition, the Bundesgerichtshof made the distinction that when the public laws of the seller's State and the buyer's State are the same, Article $35(2)(\mathrm{b}),{ }^{43}$ which deals with seller's knowledge, would permit the buyer to recover. ${ }^{44}$ Presumably, registration of IIP rights is similar in many States and therefore if the State of use is known to the seller, a duty to inquire would not be unreasonable.

The second limitation on the general requirement of Article 42 is geographical and is split into two prongs - where the goods will be used, if contemplated at time of contracting, and where the buyer has its place of business. The geographical limits reflect the concern mentioned in the Secretariat's Commentary of extending required knowledge by a seller of the IIP rights to every part of the world. ${ }^{45}$ One court applying Article 42 echoed the Secretariat's Commentary, stating that the seller guarantees "conformity in certain countries, but not on a worldwide level."

\footnotetext{
${ }^{41}$ PETER SCHLECHTRIEM, UNIFORM SALES LAW IN THE DECISIONS OF THE BUNDESGERICHTSHOF, COMMENTARY ON CISG ISSUES CONSIDERED BY THE BGH, presented in "50 Years of the Bundesgerichtshof: A Celebration Anthology from the Academic Community," available at http://cisgw3.law.pace.edu/cisg/biblio/schlechtriem3.html.

${ }^{42}$ See infra p. 13.

${ }^{43}$ CISG, supra note 3, art. 35(2)(b). "Except where the parties have agreed otherwise, the goods do not conform with the contract unless they: (b) are fit for any particular purpose expressly or impliedly made known to the seller at the time of the conclusion of the contract, except where the circumstances show that the buyer did not rely, or that it was unreasonable for him to rely, on the seller's skill and judgement [sic]."

${ }^{44}$ CLOUT Case No. 123 [Bundesgerichtshof [BGH] [Federal Court of Justice] Mar. 8, 1995, VIII ZR 159/94 (F.R.G),], available at http://cisgw3.law.pace.edu/cases/950308g3.html.

${ }^{45}$ Secretariat Commentary, supra note 2, available at http://cisgw3.law.pace.edu/cisg/text/secomm/secomm42.html.

${ }^{46}$ Oberster Gerichtstof [OGH] [Supreme Court] Sept. 12, 2006, 10 Ob 122/05x (Austria), available at http://cisgw3.law.pace.edu/cases/060912a3.html.
} 
The first geographical limitation prong is "under the law of the State where the goods will be resold or otherwise used, if it was contemplated by the parties...."47 This limitation is conditioned on the particular State being "contemplated" by both parties at the time of contracting. Professor Schlechtriem states that, in relation to the term "contemplated," "the seller's obligation in this case depends on where and how the goods are to be used according to the contract." ${ }^{\text {48 }}$ However, Professor Schlechtriem does not expand on what is meant by the phrase "according to the contract." If the contract is governed by the CISG, it is necessary to consider the principles of Article 11 and Article 8. Article 11 states that "[a] contract of sale need not be concluded in or evidenced by writing and is not subject to any other requirement as to form. It may be proved by any means - including witnesses." ${ }^{49}$ This is a rejection of the Statute of Frauds. Additionally, Article 8 deals with the intent of the parties and allows proof of intent to include "all relevant circumstances of the case including the negotiations" that would give a reasonable person notice of the other party's intent. ${ }^{50}$ Specifically, Article $8(3)$ is a rejection by the CISG of the Parol Evidence Rule. Thus it seems, when combined with these two provisions, the phrase "according to the contract" should not be limited to the exact language used in the contract and should include anything that would give the seller reasonable notice of the States in which the buyer would be considering use of the goods.

\footnotetext{
${ }^{47}$ CISG, supra note 3 , art. 42(1)(a).

${ }^{48}$ SCHLECHTRIEM, supra note 35 (emphasis original).

${ }^{49}$ CISG, supra note 3, art. 11.

${ }^{50}$ CISG, supra note 3 , art. 8.
}

(1) For the purposes of this Convention statements made by and other conduct of a party are to be interpreted according to his intent where the other party knew or could not have been unaware what that intent was.

(2) If the preceding paragraph is not applicable, statements made by and other conduct of a party are to be interpreted according to the understanding that a reasonable person of the same kind as the other party would have had in the same circumstances.

(3) In determining the intent of a party or the understanding a reasonable person would have had, due consideration is to be given to all relevant circumstances of the case including the negotiations, any practices which the parties have established between themselves, usages and any subsequent conduct of the parties. Id. 
This might lead to problems of a homeward trend in application of the CISG. For example, if the Article 42 claim is being litigated in the United States, which has a Parol Evidence Rule requiring details of the transaction to be reduced to writing, a court might not allow evidence of a phone conversation offered by the buyer as proof of an expression to the seller of the buyer's desire to resell the goods in State X when the goods are subject to a third party right or claim in State X. For this specific case in a court in the United States, it would be prudent to reduce the contemplated places of use to the contract.

A further limitation in this clause is the drafters' choice to use the singular word "State." Throughout the CISG, there are singular and plural forms of "State" used, and from each provision it is clear that the drafters meant several States when the plural form is used. ${ }^{51}$ Commentary is silent as to the purpose of the singular "State." The application of only one State is consistent with the drafters' concern of extending the requisite knowledge of the seller to indefinite jurisdictions. ${ }^{52}$ However, the singular "State" seems to revert back to the default territorial-based application of IIP rights. The Berne Convention for the Protection of Literary and Artistic Works ${ }^{53}$ (hereinafter Berne) and the Paris Convention for the Protection of Industrial Property $^{54}$ (hereinafter Paris) grant broader transnational protections for parties who possess rights or claims based on IIP allowing protection in several States once there is a recognized right of protection in one Contracting State.

Limiting Article 42 to one State could yield the unintended result of permitting the seller to choose which State to inquire into for the existence of any IIP rights that may exist in relation

\footnotetext{
${ }^{51}$ Where the plural form is used: CISG, supra note 3, art. 1 ("parties whose places of business are in different States"); CISG, supra note 3, art. 94 ("one or more non-Contracting States"). Where the singular is used: CISG, supra note 3, art. 1(b) ("when the rules of private international law lead to the application of the law of a Contracting State”); CISG, supra note 3, art. 12 (“a Contracting State which has made a declaration”).

${ }^{52}$ Secretariat Commentary, supra note 2.

${ }^{53}$ Berne Convention for the Protection of Literary and Artistic Works of 1886, May 4, 1896, 828 U.N.T.S. 221 (1988).

${ }^{54}$ Paris Convention for the Protection of Industrial Property of 1883, Mar. 20, 1883, 6 I.L.M. 806 (1967).
} 
to the goods. A hypothetical would be if the buyer and seller specify in the contract that the goods purchased will be used or resold in several States including the buyer's place of business. Although contrary to the dictates of the CISG, a court might ignore the substantive law and adjudicate the case with the goal of finding an equitable resolution. This decision by the court could depend on the relationship of the States to the parties and of the States to each other. Presumably, if the States stipulated in the contract belong to the same economic union, it would not be unreasonable to require the seller to inquire. Despite this, even if the States are all parties to a multilateral convention such as Berne or Paris, each convention allows for different rights restricted by first sale, public domain and election of the IIP right holder. Therefore, because a duty to inquire is required of the seller, it seems to follow that a seller could select one of the States included in the contract. This could leave the buyer with the challenge to prove that the seller did not inquire into a particular State. Additionally, the buyer faces the added burden of not being indemnified, even though he made known to the seller the location of the desired use.

The second geographical limitation prong is to rights or claims based in IIP "under the law of the State where the buyer has his place of business." 55 This provision is applicable when, at the time of the contracting, no States were contemplated by the parties to the contract. However, when combined with the limitations imposed on the buyer included in Article 42(2), this limitation is essentially without consequence for the seller. The first limitation on the buyer is that he may not rely on Article 42 if "at the time of the conclusion of the contract the buyer knew or could not have been unaware of the right or claim." ${ }^{, 56}$ If there are no States included in the contract by the parties, the seller's default responsibility is to know if any third party rights exist in the State where the buyer has its place of business. However it would be very unusual

\footnotetext{
${ }^{55}$ CISG, supra note 3 , art. 42(1)(b).

${ }^{56}$ CISG, supra note 3 , art. 42(2)(a).
} 
for the buyer to assert successfully that he is not aware of the IIP rights of a third party in the State in which he operates. Additionally, if the buyer is intending to use or resell the goods in another State, he could be held to a standard where he should have informed himself of the existence of any IIP rights or claims dealing with the goods he intends to use. Therefore, the seller's responsibility is limited significantly when this first restriction is placed on the buyer.

The few courts who have applied Article 42 have placed a higher threshold of knowledge on the buyer (than in relation to the seller) when the buyer has brought an action seeking indemnity from the seller. Two courts in France have held that the Article 42 protections for the buyer were inapplicable because the buyer in his "professional capacity" could not have been unaware of the infringement. In a court in Versailles, two French buyers purchased furniture from a Spanish seller which included parts that infringed on a third party's copyright. ${ }^{57}$ The court held that because the buyers had knowledge of the identity of the copyright holder and as "professionals in this area" they could not claim that they could not have been unaware of the existence of the third party's rights. ${ }^{58}$ In an Appellate Court in Colmar, a French clothing company purchased shirts from a German company that contained a combination of two types of fabric that infringed on a copyright owned by a French textile firm. ${ }^{59}$ That court held that because the buyer in his "professional capacity" could not have been unaware of the IIP rights of a third party, he could not rely on Article 42 for indemnification. ${ }^{60}$ These cases highlight the heightened level of knowledge imputed to the buyer.

\footnotetext{
57 Tribunal de grande instance [T.G.I.] [ordinary court of original jurisdiction] Versailles, Nov. 23, 2004 (Fr.), available at http://www.unilex.info/case.cfm?pid=1\&do=case\&id=998\&step=Abstract.

${ }^{58} I d$. (emphasis added).

${ }^{59}$ Cour d'appel [CA] [regional courts of appeal] Colmar, Nov. 13, 2002 (Fr.), available at http://cisgw3.law.pace.edu/cases/021113f1.html.

${ }^{60} I d$. (emphasis added).
} 
It is instructive to consider whether a change in the underlying facts would have resulted in a different outcome in these cases. First, the courts' reasoning might change if the IIP rights that were being infringed were registered in another country than that of the buyer. If IIP rights exist in State X, a seller who owns the IIP rights to the good he is selling in State S would be in a better position than the buyer to know the existence of any rights of a third party in State X. In addition, if the buyer resold or used the goods in State S, the seller should know whether he can legally sell his goods to the buyer and if not, a buyer would be entitled to indemnity under Article 42.

Both French courts placed a high level of knowledge on the buyer using the phrase "professional capacity" to evaluate whether the buyer should have known that the goods he was purchasing would infringe on the IIP rights of a third party. It is important to query through a change in the facts as to what extent "professional capacity" can be extended. If the third party IIP rights existed outside the industry of which the buyer acts in a "professional capacity," the courts' rationale that the buyer has specific knowledge of his industry is probably less applicable. That "professional capacity" language could just as easily be placed on the seller. However, if the buyer is operating on a transnational basis already, a court might expect that he has the requisite knowledge and ability to determine the existence of IIP rights in any other State in which he intends to operate. The changing fact patterns is illustrative of how a seemingly equitable analysis of which party is in the better position to know of any third party IIP rights or claims could be performed by courts. 
The buyer's remedy under Article 42 is also limited to the extent that he supplied the seller with the specifications for the goods. ${ }^{61}$ This limitation acts as a shield to liability for the seller. This shield was recognized by the Israeli Supreme Court when it held that a buyer could not recover from a seller when the buyer acquired boots that contained a mark that infringed on the trademark rights of a third party. ${ }^{62}$ In that transaction, the buyer supplied the seller with design specifications that contained the mark. ${ }^{63}$ Despite the express language of Article 42 and contrary to the principles of the CISG,${ }^{64}$ the court determined that because both parties knew that the boots would infringe upon the well-known mark of the third party, both parties were equally responsible for the infringement. ${ }^{65}$ Although the express language of Article 42 does not permit the buyer to recover from the seller when he has supplied the specifications, this decision highlights the equitable-style relief that is granted by courts evaluating the knowledge by both parties of any violation of third party rights based in IIP.

\section{Article 43 implementation requirements and procedure}

In order to rely on Article 42, the buyer must follow the requirements of Article 43 in giving "notice to the seller specifying the nature of the right or claim of the third party within a reasonable time after he has become aware or ought to have become aware of the right or claim. ${ }^{, 66}$ There are three distinct issues dealing with specificity of notice, what constitutes "reasonable time" and the level of knowledge of the buyer. Because Article 43 and Article 39 have similar requirements to pursue a remedy for receipt of goods encumbered by rights of a

\footnotetext{
${ }^{61}$ CISG, supra note 3, art. 42(2)(b). "The obligation of the seller under the preceding paragraph does not extend to cases where: (b) the right or claim results from the seller's compliance with technical drawings, designs, formulae or other such specifications furnished by the buyer." $I d$.

${ }^{62}$ S. Ct. 3912/90 Eximin v. Textile \& Footwear [1999] IsrSC 47(iv) 64 (Isr.), available at http://cisgw3.law.pace.edu/cases/930822i5.html.

${ }^{63} I d$.

${ }^{64}$ Arie Reich, The Uniform Law on International Sales: A Need for Revision, 14 BAR-ILAN L. STUD. 127, 144-47 \& 166-68 (1997), available at http://www.biu.ac.il/LAW/cisg/cisgArtEng.htm.

${ }^{65}$ Eximin, supra note 62.

${ }^{66}$ CISG, supra note 3, art. 43.
} 
third party and non-conforming goods, respectively, an analysis of the articles together is instructive.

The notice given should be sufficiently detailed as to give the seller an opportunity to obtain and present evidence on the conditions of the goods. ${ }^{67}$ In deciding whether the notice complied with Article 39 requirements, a German court held that specificity was lacking when a buyer sent notice to the seller claiming that the goods "did not conform to our specifications and cannot be sold to customers." ${ }^{68}$ In commentary to Article 39, it is noted that the purpose of the notice is to permit the seller to decide what steps to take next: "by examining the goods himself, by repairing the goods, or by delivering substitute goods." 69 Additionally, a seller could have the ability to cure the defect ${ }^{70}$ by negotiating a license with the holder of the IIP rights.

Although the enumerated performance remedies would be lacking in the case of an Article 42 claim, the seller would need to be able to tell the buyer whether the claim is rightful in order to avoid cancellation of the contract by the buyer. If the claim is indeed unsuccessful, the buyer could still use the goods as he had originally intended and the seller would be required to indemnify the buyer for costs related to the litigation - as long as it was not frivolous. Although it was mentioned previously that the seller is indemnifying the buyer against rights or claims, it seems unlikely that in light of an unsuccessful claim, a buyer would want to return the goods to the seller for refund of purchase price. Additionally, a buyer may be required to mitigate

\footnotetext{
${ }^{67}$ Honnold Treatise, supra note $12, \S 256$, available at http://www.cisg.law.pace.edu/cisg/biblio/ho39.html\#256.

${ }^{68}$ Id. (citing Oberlandesgericht in München [OLG] [trial court for selected criminal matters and court of appeals] July 9, 1997, 7 U 2080/97 (F.R.G.), available at http://www.cisg.law.pace.edu/cisg/wais/db/cases2/970709g1.html).

${ }^{69}$ Franco Ferrari, Tribunale di Vigevano: Specific Aspects of the CISG Uniformly Dealt With, 20 J.L. \& CoM. 22539 (2001), available at http://www.cisg.law.pace.edu/cisg/biblio/ferrari6.html\#vii.

${ }^{70}$ CISG, supra note 3, art. 48(1).

Subject to article 49, the seller may, even after the date for delivery, remedy at his own expense any failure to perform his obligations, if he can do so without unreasonable delay and without causing the buyer unreasonable inconvenience or uncertainty of reimbursement by the seller of expenses advanced by the buyer. However, the buyer retains any right to claim damages as provided for in this Convention. Id.
} 
damages by selling the goods that he possesses without any encumbrance. ${ }^{71}$ Regardless of the exact remedy agreed upon by the parties, in order for a seller to reasonably apprise himself of the claims of a third party, the notice would need to include: the country in which the IIP right is registered, the date of registration, the terms of registration and any licenses granted by the third party asserting the right or claim based in IIP. It might not be enough for the buyer to tell the seller that a third party has asserted that it owns the rights to the goods of which the buyer is in possession.

In light of the required degree of specificity in the notice given, the buyer may have to wait for the specific claim by the third party to be filed or engage in detailed communication with the third party over an extended period of time. The delay for creating notice with a certain degree of specificity might run afoul of the reasonable time requirement of Article 43 . Under the Article 39 formulation, German courts have embraced Ingeborg Schwenzer's "noble month" time period for reasonable time. ${ }^{72}$ Other courts have extended the reasonable time requirement based on the circumstances of the particular case. ${ }^{73}$ In dealing with claims or rights based in IIP, it seems a court could reasonably extend the time period for effective notice until the buyer gets all the information from the third party. Due to the fact that the CISG is premised on amicable dealings between the buyer and seller, despite not qualifying for effective notice due to a lack of specificity, a buyer should notify the seller once he learns of the possibility of a third party right or claim. This will also permit the buyer to accurately make a claim for damages as a result of not being able to use or resell the goods once a third party makes the claim it owns the legal

\footnotetext{
${ }^{71}$ CISG, supra note 3, art. 77.

72 INGEBORG SCHWENZER, COMMENTARY ON THE UN CONVENTION ON THE INTERNATIONAL SALE OF GOODS (CISG), Art. 39 (Peter Schlechtriem \& Ingeborg Schwenzer eds., 2d ed. 2005).

${ }^{73}$ Daniel Girsberger, The Time Limits of Article 39 CISG, 25 J.L. \& COM. 241, 244 (2005), available at http://www.cisg.law.pace.edu/cisg/biblio/girsberger.html.
} 
rights to the goods. Therefore, if necessary, the buyer will be able to point to a specific date on the calendar for any future damage remedies.

Where the time for making a claim of non-conformity is limited by the two year limitation of Article 39(2), unless inconsistent with a contractual period of guarantee, no similar outer limit exists under Article 43. Thus a "seller must take into account that claims based on defective legal title may be asserted for the duration of the applicable statute of limitations."74 When the seller inquires into the State contemplated by the parties at the time of contracting, he should also be mindful of the statute of limitations applicable in that State. The statute will begin to run once the buyer places the goods into the market of the third party's State, which could theoretically be at any point after the buyer has received the goods.

The knowledge prong of Article 43 is different from and illustrates a disconnect with the knowledge requirement within Article 42. While Article 42 provides "knew or could not have been unaware," Article 43 states "aware or ought to have become aware." As discussed in the Article 42 knowledge analysis, Professor Honnold suggested that "ought to have known" signifies a duty to inquire. ${ }^{75}$ The duty to inquire is consistent when applied with Article 39 requiring the buyer to inspect the goods within a reasonable time after receipt. In that article, the duty is placed on the buyer in order to give the seller confidence in the conclusion of the dealing with the buyer. If the defect in the goods cannot be found upon inspection, Article 39 places the two year time period on the buyer. Thus, at some point between the time of actually handing over the goods to the buyer and two years from that point, the seller will have been notified of any defects. In relation to a legal defect in the goods, the "ought to have become aware" language does not seem to require the buyer to make inquiries into the States in which he plans

\footnotetext{
${ }_{75}^{74}$ Schlechtriem, supra note 35, available at $\mathrm{http}: / /$ www.cisg.law.pace.edu/cisg/biblio/schlechtriem-43.html.

${ }^{75}$ See supra p. 9 and note 12.
} 
to use or resell the goods before he commences such use. The requirement placed on the buyer seems to be that any event giving rise to a concern by a layperson as to the status of the goods purchased will result in knowledge, and the reasonable time period will begin to run from this point. This results in uncertainty on the part of the seller as to the conclusion of the transaction.

The interplay of the three requirements could pose a serious problem for the buyer; because while he will have to give specific enough notice for it to be effective, he will not be able to do so until he has more information. Yet, if he waits to receive more information, it might be an unreasonable delay on his part from the time he ought to have become aware of the third party right or claim. This problem is illuminated in the German automobile case. ${ }^{76}$ In that case, a car dealership in the Netherlands acquired an automobile from a seller in Germany. After acquiring the vehicle and the title documentation, Dutch police seized the car on the suspicion that the car had been stolen in France. The court held that the buyer could not pursue remedy for legal defect because he did not give the seller notice of the legal defect within a reasonable time after learning of it. Although the court acknowledged that reasonable time depends on the facts of the specific case and the buyer in this case pursued a legal evaluation before contacting the seller, the court determined that "for a legal layperson such as [Buyer], the suspicion of theft, made obvious by the police seizure, was easily recognized as an especially significant occurrence without the need to secure legal advice." ${ }^{, 77}$ The problem in this case is reconciling the amount of detail required in the notice with the requirement that it be timely. As mentioned previously, in the case of a right or claim based in IIP, there may be problems with how effective the notice is in order to proceed under the Article 42 protections.

\footnotetext{
${ }^{76}$ Bundesgerichtshof [BGH] [Federal Court of Justice] Jan. 11, 2006, VIII ZR 268/04, translation at http://cisgw3.law.pace.edu/cases/060111g1.html.

${ }^{77} I$.
} 
Despite these requirements on the buyer for specificity and timeliness of notice, a seller could not rely on this to defeat a claim by the buyer if the seller had knowledge of the third party right or claim based in IIP. ${ }^{78}$ In relation to this provision, it is illustrative to note that the knowledge requirement of the seller is whether he "knew." There is no duty to inquire imposed by Article 43. However, when Article 43 is combined with Article 42's requirements on the seller, the seller would have already inquired into the existence of any third party IIP rights. There is no comparable knowledge clause in Article 39. The difference is likely due to the fact that physical conformity of the goods can be tested or judged when the goods are transferred to the buyer's possession. However, an encumbrance due to legal defect in title cannot readily be detected by the buyer. It is only when the buyer receives a cease and desist letter or a lawsuit after already selling the goods that he would become aware of any defect.

Article 42 poses unique questions for the buyer and seller when facing dispute resolution. The specific language and the limited court decisions strictly limit the buyer's abilities to recover against a seller. These limitations combined with the catch- 22 notice and reasonable time interplay of Article 43 could leave a buyer with goods he is unable to sell, a possibly successful infringement claim of a third party and no recourse against a seller.

\section{Counterfeit goods as non-conforming to the contract under Article 35}

Operating within the parameters and express language of Article 42 of the CISG can possibly leave the buyer without a remedy against the seller. Although Article 42 expressly deals with rights or claims based in IIP, it might be possible for the buyer to choose to proceed under the CISG non-conformity articles for counterfeit goods. Counterfeit goods are defined as imitation goods passed off by the seller as authentic. The possibility that goods encumbered by a third party claim based in IIP was mentioned previously in discussing applicable provisions of

\footnotetext{
${ }^{78}$ CISG, supra note 3, art. 43(2).
} 
the ULIS. ${ }^{79}$ That discussion noted that under ULIS Article 33, conformity was determined in regard to delivery, but Article 35 does not deal with delivery. ${ }^{80}$ Thus, a discussion of whether a buyer can proceed under Article 35 is not foreclosed by the applicability of Article 42.

CISG Article 35 requires that the seller "deliver goods which are of the quantity, quality and description required by the contract...." fit for the purposes for which goods of the same description would ordinarily be used." ${ }^{\text {}}$ According to the Secretariat's Commentary, the phrase "ordinarily be used" also "covers a buyer who has purchased" for resale as opposed to use. ${ }^{83}$ Additionally the Secretariat stipulates that the goods "must be honestly resalable in the ordinary course of business." certainly included within the protections of Article 35 under which an infringement claim could possibly arise.

Although goods should be capable of being resold, the level of quality remains at issue. Professor Honnold suggests that the purposes clause of Article 35 requires "merchantable quality" similar to the UCC. ${ }^{85}$ UCC $§ 2-314(2)$ states that goods are merchantable when they "pass without objection in the trade under the contract description" and "are fit for the ordinary

${ }^{79}$ See supra pp. 5-6.

${ }^{80}$ Match-up of CISG Article 35 with ULIS provisions (Comments), available at http://cisgw3.law.pace.edu/cisg/text/matchup/matchup-u-35.html.

${ }^{81}$ CISG, supra note 3, art. 35(1).

${ }^{82}$ CISG, supra note 3 , art. 35(2)(a).

Except where the parties have agreed otherwise, the goods do not conform with the contract unless they:

(a) are fit for the purposes for which goods of the same description would ordinarily be used;

(b) are fit for any particular purpose expressly or impliedly made known to the seller at the time of the conclusion of the contract, except where the circumstances show that the buyer did not rely, or that it was unreasonable for him to rely, on the seller's skill and judgement [sic];

(c) possess the qualities of goods which the seller has held out to the buyer as a sample or model;

(d) are contained or packaged in the manner usual for such goods or, where there is no such manner, in a manner adequate to preserve and protect the goods. Id. art. 35(2).

${ }^{83}$ Secretariat Commentary, supra note 2, art. 35, II 5, available at http://cisgw3.law.pace.edu/cisg/text/secomm/secomm-35.html.

${ }^{84} I d$.

${ }^{85}$ Honnold Treatise, supra note 12, available at http://cisgw3.law.pace.edu/cisg/biblio/ho35.html. 
purposes for which such goods are used." ${ }^{, 86}$ Professor Jacob Ziegel would make the standard much higher. He states that the test for merchantability is if the buyer knew of the defects he would have purchased "the goods without an abatement on the price." 87 If any change in price would have resulted, the goods would be deemed to be non-merchantable even if they would be fit for a particular end use. ${ }^{88}$ One commentator has noted in the debate between whether the standard is merchantable quality or average quality that "a Canadian proposal that goods should be of average quality was withdrawn, since several common law countries did not support it." ${ }^{, 89}$ Therefore, it seems clear that the threshold is merchantability such that the goods could be resold at the price in which the buyer expected to resell them.

If the buyer received counterfeit goods when he was expecting genuine goods, it seems consistent with the previous analysis that the goods would be non-conforming to the contract. Although the goods received could ostensibly perform the same function as the authentic goods, the buyer would not be able to honestly pass off the goods as authentic. In addition, the buyer would not be able to resell them at the same price he would have been able to as if they were authentic. The conclusion that a buyer could rely on both provisions, Article 35 and Article 42, is buttressed by the Secretariat's Commentary to Article 39 which states that the seller's two obligations: (1) to deliver goods that conform to the contract, and (2) to deliver goods free from right or claim of a third party, are independent of each other. ${ }^{90}$

\footnotetext{
${ }^{86}$ U.C.C. $\$ 2-314(2)(2001)$.

${ }^{87}$ See Jacob S. Ziegel, Report to the Uniform Law Conference of Canada on Convention on Contracts for the International Sale of Goods (1981), http://cisgw3.law.pace.edu/cisg/text/ziegel35.html.

${ }^{88} I d$.

${ }^{89}$ René Franz Henschel, Interpreting or Supplementing Article 35 of the CISG by using the UNIDROIT Principles of International Commercial Contracts and the Principles of European Contract Law, If f (2004), http://cisgw3.law.pace.edu/cisg/biblio/henschel.html.

${ }^{90}$ Secretariat Commentary, supra note 2, art. 39, available at http://www.cisg.law.pace.edu/cisg/text/secomm/secomm-39.html.
} 
The decision for the buyer whether to pursue a remedy under Article 35 or Article 42 will turn on the implementing articles, 39 and 43, respectively. In this decision, it is important for the buyer to note the differences in timing available under either article. While Article 39 requires that the buyer inform the seller of non-conformity within two years after the goods have been turned over to the buyer by the seller, Article 43 imposes no such limitation. Thus, a buyer who purchases counterfeit goods might not be able to determine that the goods are indeed counterfeit, as they appear to be real, within this time period. In that case, the buyer must rely on Article 43(2) that the seller knew of the rights of a third party in relation to the goods sold to avoid any timeliness issues of notice and the two year limitation.

In conclusion, although the buyer could proceed under Article 35; for reasons of notice, avoidance of a time limit on finding the legal defect and no difference in substantive remedy under either article, the buyer should proceed under the requirements of Article 43 in pursuing remedy for breach of a seller's duty to deliver goods free from third party rights or claims based in IIP.

\section{The Practitioners' Corner: A short guide to dealing with industrial and intellectual rights vested in a third party in the transnational sale of goods}

With any transnational legal system, problems with implementation must be anticipated and the parties must draft accordingly. CISG Article 42 poses significant uncertainty to buyers and sellers of goods predominantly as a result of the minimal level of case law and subsequent scholarly commentary. It is true that the uncertainty could be assuaged if buyers and sellers employ Article 42 as the substantive law to govern disputes resulting from the claim of a third party based in IIP. Despite the altruistic objective of creating predictable uniform contract law, the risks associated with operating under substantive rules as malleable as Article 42 are substantially great and could result in significant financial loss for the parties. 
In light of the difficulties expounded on in this note, the applicability of the CISG to any rights or claims based in IIP should be eliminated during contract negotiations. However, a body of substantive law must apply to the contract. As discussed, domestic law has traditionally governed defects in legal title. The parties may choose to apply domestic law to the transaction. The question then centers on a conflicts of law analysis in determining which domestic law to apply to the transaction with the issue turning most often on place of performance. Therefore, to avoid this further inquiry, the parties should attempt to insert clauses into the contract for protection of their interests.

A sample contract clause to protect the buyer's interests would be:

Seller shall indemnify Buyer for any losses as a result of any claim of infringement based in intellectual property, as defined by the WIPO Convention, made by a third party at any time. Seller will refund the purchase price of the contract without a requirement of mitigation by the buyer. In addition to refunding the purchase price, Seller will reimburse Buyer the costs related to freight and those incurred in any legal proceeding, regardless of whether the third party prevails or whether the claim is deemed frivolous under the domestic law of the State in which the claim is brought.

This clause attempts to grant the buyer as much protection as possible. Primarily, the buyer is concerned with being indemnified for any claim made. While this is consistent with application of the CISG, this clause will allow the buyer to receive compensation for any claim made by any third party. The clause also eliminates the geographical limitation in Article 42 . This enables the buyer to use the goods in any State and permits him to alter his plans after the conclusion of the contract. The clause also states that the remedy will be damages as opposed to specific performance. In addition any requirement of mitigation is removed - thus eliminating any further responsibility of the buyer in relation to the goods. This clause would be the ideal clause from the buyer's point of view because it removes the uncertainty of the CISG and grants 
full protection and places the knowledge requirement on the party who is in the best position to know of the existence of any IIP claims or rights related to a product it sells.

Two sample contract clauses to protect the seller's interests would be:

Buyer will provide the Seller with specifications and design drawings of the goods desired. The Seller will not indemnify the Buyer for any claims or rights made in relation to the goods furnished. This contract is to be governed by the CISG.

Seller will indemnify Buyer for any successful claim based in intellectual or industrial property as defined by the WIPO Convention made by a third party based on the law of the Buyer's place of business, except when at the time of the conclusion of the contract the Seller had purchased licenses for the goods from the third party or if the third party applied for intellectual or industrial property protection through a provisional application.

The Buyer loses the right to rely on a lack of conformity of the goods if he does not give the Seller notice thereof within a period of two years from the date on which the goods were actually handed over to the buyer. If the rights are in the public domain of the Seller's State, the Seller will not indemnify the Buyer for any claims made by a third party under the law of any other State.

The first clause grants the seller the utmost protection. Under Article 42, the seller is shielded from liability if the buyer furnishes the seller with specifications of design. Although the protection of Article 42 seems conclusive as to any dispute for indemnification, the discussion of the Israeli Supreme Court case infra illustrates how a seller and buyer could both be held responsible for infringing on a third party's IIP right. Therefore, the section of the clause that denies any indemnity for the buyer will further insulate the seller.

The second clause seems like a more likely starting point for the seller in negotiations with the buyer because it permits some level of indemnification of any claim made by a third party based in IIP. Firstly, this clause is limited by the term "successful claim." It prevents the 
seller from being held liable to any claim made by a third party. Second, the knowledge requirement is limited to the buyer's place of business. This places the seller and buyer on the same footing in ascertaining if IIP rights exist in that State. The clause also borrows language from Article 39 that requires the buyer to give the seller notice within two years of the buyer having knowledge of the claim. This supplants any statute of limitations period that could exist in the State. Therefore, the seller will be able to determine when the transaction has come to a close - the statute of limitations for a claim of infringement plus two years. The seller is also shielded if the process or mark has fallen into the public domain in its State. This limits the requirement on inquiring into whether their IIP rights vested in a third party in the buyer's state and thus diminishes the transaction costs.

These contract clauses will probably not be agreed to by the other party, but serve to highlight the interests of each part - as well as the importance of contracting out of the CISG. Due to the interest of predictability and certainty, the parties should avoid leaving any issues dealing with IIP rights or claims by a third party to the CISG as the substantive law.

\section{Conclusion}

A buyer and seller engaging in a transnational sales transaction that deals with goods that may be encumbered by a third party's right based in IIP should contract out of the CISG. The CISG does not adequately provide the buyer with a remedy against the seller if a third party claim based in IIP is asserted. The need to eliminate the applicability of the CISG is dictated by the inherent tension between the territorial-based IIP rights granted by each State individually and the desire for ease in international business. Although two distinct articles of the CISG Articles 42 and 35 - grant the buyer a remedy against the seller, these articles leave the parties in a precarious and uncertain position. The problems with the plain language of the articles, the 
inconsistent interaction with any domestic law applicable and the trend amongst courts in reaching equitable relief, make an innocuous and helpful article of substantive law a wolf in sheep's clothing. 